\title{
Variabilidade Genética de Acessos de Aguapé Coletados no ESTAdo de SÃo PAULO ${ }^{1}$
}

\author{
Genetic Variability of Waterhyacinth Accesses Collected in São Paulo State Reservoirs
}

\author{
CARDOSO, L.R. ${ }^{2}$, MARTINS, D. ${ }^{3}$, KURAMAE, E.E. ${ }^{3}$, TANAKA, R.H. ${ }^{4}$ e MORI, E.S. ${ }^{3}$
}

\begin{abstract}
RESUMO - No presente trabalho foram coletados acessos de Eichhornia crassipes (aguapé) nos reservatórios das hidrelétricas de Barra Bonita, Bariri, Três Irmãos, Ilha Solteira, Salto Grande, Promissão, Ibitinga, Nova Avanhandava, Mogi-Guaçu, Euclides da Cunha, Jaguari, Jurumirim, Jupiá, Paraibuna e Porto Primavera, do Estado de São Paulo. Estes acessos foram submetidos a um estudo de variabilidade genética por meio de RAPD. Os "primers" utilizados foram OP X02, OP X07, OP X11 e OP P10 (TTCCGCCACC, GAGCGAGGCT, GGAGCCTCAG, TCCCGCCTAG, respectivamente). Dentre os acessos coletados e analisados, 21 apresentaram indice de identidade genética acima de 0,90. O dendrograma gerado com dados entre populações revelou forte coerência com a distribuição geográfica dos reservatórios que continham as plantas de aguapé. A variabilidade genética encontrada entre os acessos coletados nos diferentes reservatórios estudados foi elevada, considerando que a principal via de reprodução dessa espécie é a vegetativa.
\end{abstract}

Palavras-chave: planta aquática, DNA, dispersão, Eichhornia crassipes.

\begin{abstract}
Accesses of Eich hornia crassipes (waterhyacinth) were collected in hydroelectric reservoirs from fifteen power plants: Barra Bonita, Bariri, Três Irmãos, Itha Solteira, Salto Grande, Promissão, Ibitinga, Nova Avanhandava, Mogi-Guaçú, Euclides da Cunha, Jaguari, Jurumirim, Jupiá, Paraibuna and Porto Primavera in the state of São Paulo. The genetic variability of these accesses was studied by RAPD, and the primers used were OP X02, OP X07, OP X11, OP P1O. Among the accesses collected and analyzed, 21 presented an index of genetic identity above 0.90. The dendrogram generated by the data between populations was correlated with the geographic distribution of waterhyacinth plant reservoirs. Although waterhyacinth dispersion is via vegetative propagation a high genetic variability among the collected accesses was observed.
\end{abstract}

Key words: aquatic plant, DNA, Eichhornia crassipes, weeds, dispersion.

\section{INTRODUÇÃO}

A eutrofização de corpos hídricos no Brasil é geralmente causada pelo lançamento de dejetos dos grandes centros urbanos ou pelo carreamento de fertilizantes utilizados na agricultura. Esse processo fornece condições nutricionais favoráveis para que ocorra desenvolvimento desordenado das espécies de plantas aquáticas presentes no ambiente. Muitos são os danos gerados nessas situações extremas. Do ponto de vista ambiental, algumas espécies de crescimento rápido podem suprimir outras menos agressivas, desejáveis para manutenção da diversidade, ou modificar negativamente algumas características físicas da água. Dentre os relevantes impactos sociais pode-se citar o acúmulo de lixo, que serve de

1 Recebido para publicação em 15/11/2001 e na forma revisada em 24/12/2001.

Parte da dissertação do primeiro autor apresentada para obtenção do título de Mestre.

2 Eng.-Agr., M.S. FCA-UNESP, Caixa Postal 237, 18603-970 Botucatu-SP; ${ }^{3}$ Professor Dr., Departamento de Produção Vegetal, FCA-UNESP. ${ }^{4}$ Dep. de Meio Ambiente, CESP. 
habitat para insetos vetores de doenças humanas, além de imprimir prejuízos às atividades de navegação, pesca e geração de energia elétrica.

Das plantas emergentes flutuantes livres, o aguapé (Eichhornia crassipes) é considerado uma das espécies mais importantes como planta daninha, devido à sua capacidade de reprodução e crescimento (Swarbrick, 1981). Verdadeiras ilhas de plantas de aguapé chegam até as grades de captação de água de usinas hidrelétricas, rompendo-as e interrompendo o funcionamento das turbinas. Os possíveis danos a essa atividade e àquelas ligadas ao bem-estar social, como prática de esportes náuticos e pesca, traduzem a necessidade de estudos que esclareçam questões relacionadas ao manejo das plantas daninhas aquáticas.

Em razão da crescente importância das plantas daninhas aquáticas, a biologia molecular vem se tornando uma importante ferramenta para o seu conhecimento. Pesquisas sobre variabilidade genética com o uso de marcadores moleculares em plantas permitem avaliar sua origem e dispersão. Ryan (1993a) usou "primer" G17 (seqüência: 5'ACG-ACCGACA3') e o método de RAPD para caracterizar biotipos monóicos e dióicos de Hydrilla verticillata (L.F.) Royle e verificou que o "primer" G17 foi capaz de distinguir dois biotipos das populações estudadas. Em outro trabalho, esse mesmo pesquisador, usando a técnica de RAPD, constatou que as plantas de Hydrilla verticillata encontradas em Tulare, EUA, eram similares ao biotipo monóico da coleção do Departamento de Agricultura dos Estados Unidos e eram distintas do biotipo dióico (Ryan, 1993b).

Em outro trabalho, Weiss (1997) comparou a variabilidade genética entre acessos de Egeria densa coletados na Califórnia e de outras localidades. O pesquisador procurou elucidar a origem da introdução dessas plantas na América do Norte, uma vez que elas não produzem sementes e são difundidas por fragmentação, além de não apresentarem nenhuma parte da raiz viável e capaz de produzir uma nova planta. Com base no dendrograma criado com dados das análises de RAPD, concluiu-se que a Elodea canadensis era geneticamente diferente da Egeria densa. Acessos coletados na Nova Zelândia pareceram ser geneticamente isolados quando comparados com a Egeria densa da região da Califórnia. Plantas da região e de lojas de aquário locais e da Carolina do Norte apresentaram pequenas variações. Em virtude dessa diferença entre as plantas e da incapacidade de a Egeria densa reproduzir-se sexuadamente, o pesquisador concluiu que foram provavelmente introduzidas da mesma população oriunda da América do Sul, além de se observar que as plantas da Nova Zelândia são geneticamente isoladas e que foram introduzidas de uma diferente população nativa da América do Sul. O pesquisador sugeriu, ainda, que a próxima etapa do trabalho seria fazer um estudo da variabilidade genética das plantas Egeria densa da América do Sul.

O presente trabalho teve por objetivo determinar a possível existência de variabilidade genética de plantas de aguapé em diferentes reservatórios de produção de energia elétrica do Estado de São Paulo.

\section{MATERIAL E MÉTODOS}

Foram amostrados, devido à diferença de infestação, no máximo 16 pontos de coleta em cada reservatório de hidrelétricas do Estado de São Paulo. Os locais de coleta e números de pontos coletados foram: Barra Bonita (BAB) 15, Bariri (BAR) 15, Três irmãos (TRI) 09; Ilha Solteira (ILS) 13, Salto Grande (SAG) 15, Promissão (PRO) 12, Ibitinga (IBI) 14, Nova Avanhandava (NAV) 13, Mogi-Guaçu (MOG) 15, Euclides da Cunha (EUC) 16, Jaguari (JAG) 16, Jurumirim (JUR) 16, Jupiá (JUP) 16, Paraibuna (PAR) 09 e Porto Primavera (PPR) 16. Foram amostrados no máximo 16 pontos de coleta, em virtude da diferença de infestação entre os reservatórios. Em cada ponto, que representa uma planta, foram anotadas as coordenadas geográficas por meio de GPS portátil.

Pode-se observar, na Figura 1, a representação do mapa do Estado de São Paulo com os reservatórios percorridos. Nota-se que todas as bacias hidrográficas do Estado foram contempladas com campanhas de coleta.

Após as coletas a campo dos acessos, estes foram acondicionados em caixas d'água na área experimental do Núcleo de Pesquisas Avançadas em Matologia (NUPAM), ligado ao Departamento de Produção Vegetal da Faculdade de Ciências Agronômicas, UNESP, campus de Botucatu-SP. 


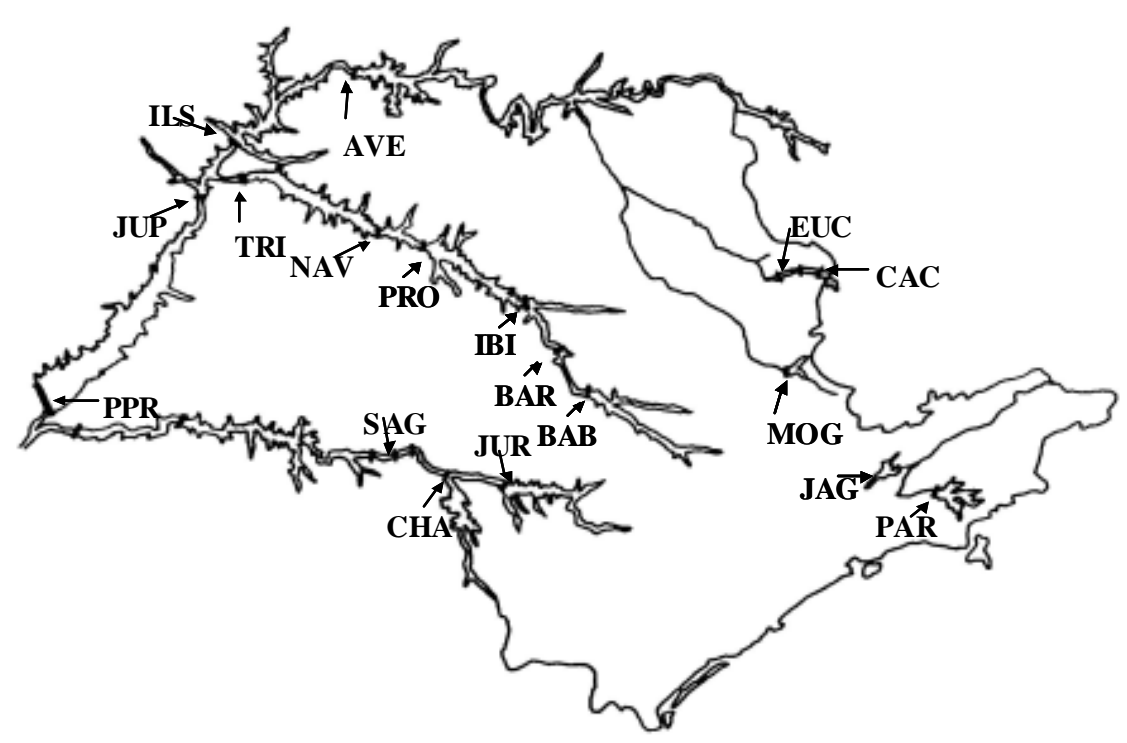

Figura 1 - Reservatórios do Estado de São Paulo percorridos para coleta de plantas de aguapé, 1998/99.

Cada caixa foi dividida por placas de isopor em quatro partes, para comportar quatro plantas previamente identificadas com etiquetas. As plantas foram dispostas seguindo a seqüência de ordem de coleta.

Parte do material vegetal de folhas jovens foi submetido à extração de DNA nuclear segundo Lodhi et al. (1994), para analisar a variabilidade genética entre os possiveis acessos de aguapé coletados. Utilizou-se a técnica de RAPD com base no protocolo de Williams et al. (1990).

As reações foram amplificadas utilizandose os "primers" da operon X02 (TTCCGCCACC), X07 (GAGCGAGGCT), X11 (GGAGCCTCAG), P 10 (TCCCGCCTAG), em termociclador PTC-100 da MJ Research, Inc. As amostras foram corridas em gel de agarose $1,5 \%$ a $110 \mathrm{~V}$ por três horas. Utilizaram-se $12 \mu \mathrm{L}$ de Ladder $100 \mathrm{pb}$ como marcador e $4 \mu \mathrm{L}$ de tampão de carregamento como corante, para permitir visualização no "Eagle Eye II".

As análises foram realizadas no programa computacional POPGENE 32.

\section{RESULTADOS E DISCUSSÃO}

Os padrões de bandas gerados pelas reações de RAPD foram nítidos e produziram bandas de média a boa intensidade. Os quatro "primers" utilizados permitiram boa amplificação de todas as amostras e demonstraram a existência de variabilidade genética entre as populações, produzindo bandas polimórficas. Na Figura 2 está apresentado o padrão obtido com o "primer" $\mathrm{X} \mathrm{07,} \mathrm{o} \mathrm{qual} \mathrm{permite} \mathrm{a} \mathrm{visualização} \mathrm{das} \mathrm{bandas}$ de amostras referentes aos reservatórios de BAR, SAG, BAB e JAG.

Esse resultado contrapõe-se ao de Wain \& Martin (1980), citados por Wain et al. (1985), ao concluírem que, apesar de no estado da Flórida existirem plantas de aguapé de três formas de crescimento diferentes, as plantas eram geneticamente indistinguiveis. Portanto, a análise de 14 zonas de atividade enzimática utilizada por estes autores foi menos eficiente que RAPD para detectar variabilidade genética entre plantas de aguapé.

Dos quatro "primers" utilizados, foram escoradas 16 bandas consideradas fidedignas e reproduziveis. Na Tabela 1 constam o número e a percentagem de locos polimórficos para cada reservatório onde foram coletadas as amostras. A média de número de locos polimórficos por "primer" foi de 7, variando desde $1 \mathrm{em}$ Paraibuna a 12 em Bariri.

Dependendo do reservatório, a percentagem de polimorfismo não foi grande, apesar de o número de locos ter sido relativamente alto. Analisando o número de locos polimórficos de todas as populações, os reservatórios de 
Barra Bonita e Paraibuna apresentaram percentagem baixa, indicando que essas populações foram comparativamente menos variáveis que as demais.

A variabilidade genética revelada pela análise de dados dos marcadores RAPD foi muito coerente com a distribuição geográfica dos reservatórios nos quais foram coletadas as plantas e considerada alta para o aguapé, uma vez que essa planta aquática é originária da América do Sul e se multiplica principalmente por reprodução vegetativa, apesar de eventual reprodução por sementes. Na Figura 3 está representado o dendrograma de distância genética construído com dados calculados com base em Nei (1972), obtidos pelo coeficiente de similaridade simple matching. Dois grupos foram formados. Do primeiro grupo, os reservatórios de Bariri e Ibitinga são os que possuem material mais próximo geneticamente, com indice de identidade genética igual a 0,9637; ressalta-se que os reservatórios de Bariri, Ibitinga, Promissão, Nova Avanhandava e Jupiá localizam-se em seqüência a jusante no rio Tietê. O reservatório de Porto Primavera faz parte do rio Paraná, mas seu material foi muito parecido geneticamente com o de Jupiá, por estar a jusante segundo o fluxo da água; apesar de Ilha Solteira estar a montante, a proximidade física garante as similaridades.

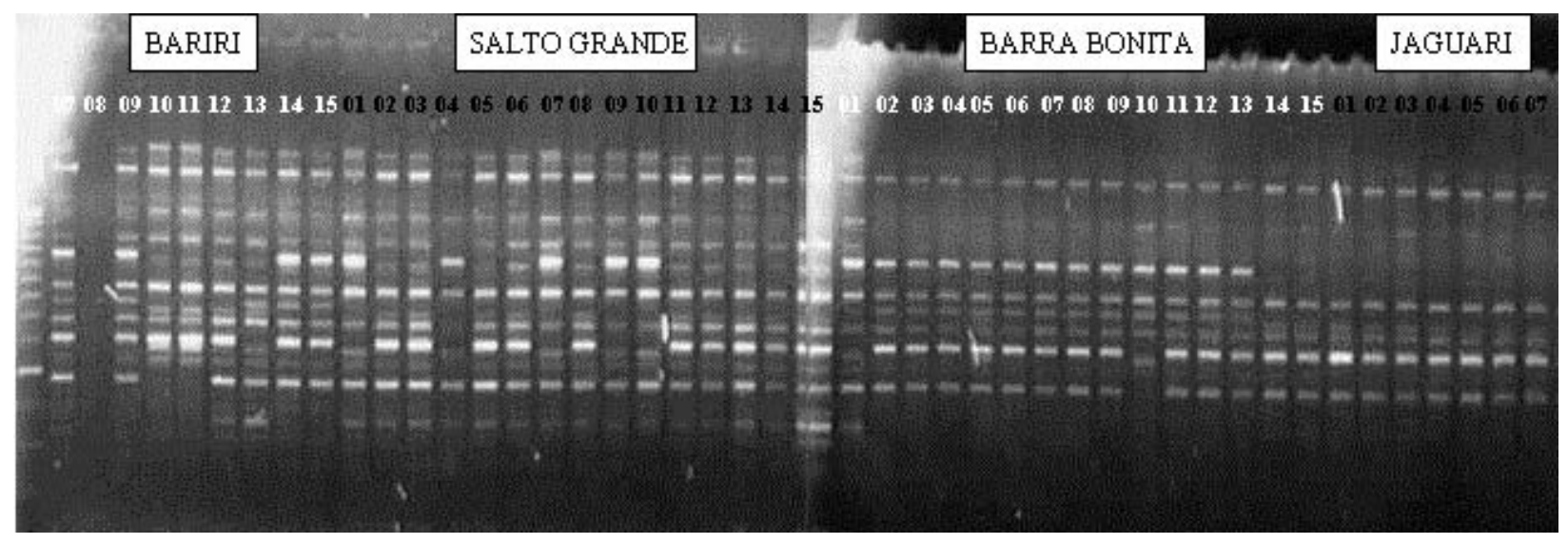

Figura 2 - Padrão de bandas amplificadas por RAPD com o “primer” X 07, de amostras dos reservatórios de Bariri, Salto Grande, Barra Bonita e Jaguari, pertencentes ao Estado de São Paulo.

Tabela 1 - Porcentagem e número de locos polimórficos para as 15 populações

\begin{tabular}{|l|c|c|}
\hline \multicolumn{1}{|c|}{ Local de coleta } & $\begin{array}{c}\text { \% de locos } \\
\text { polimórficos }\end{array}$ & $\begin{array}{c}\mathrm{n}^{\text {o }} \text { de locos } \\
\text { polimórficos }\end{array}$ \\
\hline Nova Avanhandava & 50,00 & 8 \\
Mogi-Guaçu & 31,25 & 5 \\
Promissão & 43,75 & 7 \\
Ilha Solteira & 62,50 & 10 \\
Ibitinga & 68,75 & 11 \\
Bariri & 75,00 & 12 \\
Salto Grande & 62,50 & 10 \\
Barra Bonita & 6,25 & 9 \\
Jaguari & 25,00 & 4 \\
Jurumirim & 12,50 & 2 \\
Euclides da Cunha & 12,50 & 2 \\
Porto Primavera & 68,75 & 11 \\
Jupiá & 43,75 & 7 \\
Paraibuna & 6,25 & 1 \\
Três Irmãos & 37,50 & 6 \\
\hline Média & 40,42 & 7 \\
\hline
\end{tabular}

$\begin{array}{llllllllllllllll}0,30 & 0,28 & 0,26 & 0,24 & 0,22 & 0,20 & 0,18 & 0,16 & 0,14 & 0,12 & 0,10 & 0,08 & 0,06 & 0,04 & 0,02 & 0,00\end{array}$

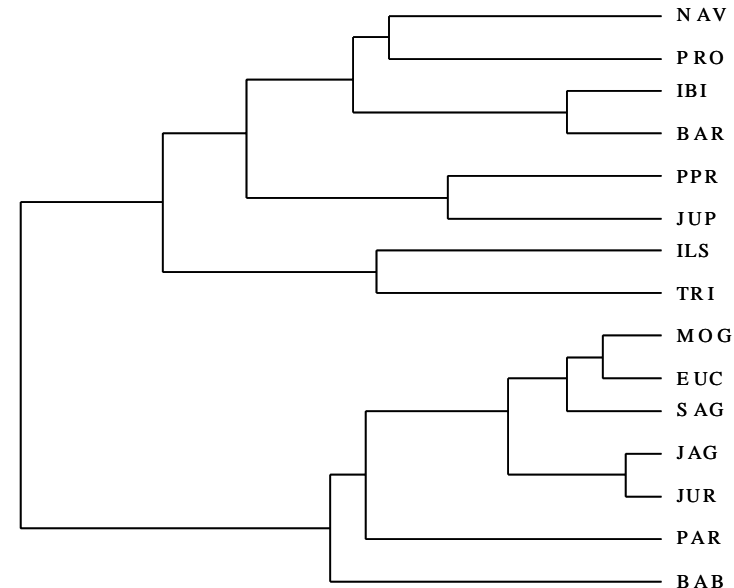

Figura 3 - Dendrograma de distância genética entre as populações, obtido pelo coeficiente de similaridade simple matching. 
Pode-se observar que o material de Barra Bonita distanciou-se, no dendrograma, dos demais reservatórios do rio Tietê. O reservatório de Barra Bonita converge águas dos rios Tietê e Piracicaba. A vazão do rio Tietê corresponde a 63\% da vazão do afluente ao qual pertencem; assim, pode ter contribuído com mais material dispersado nos reservatórios subseqüentes. Contudo, o menor número de coletas realizado no rio Piracicaba pode ter sido a causa da distância de BAB no dendrograma.

Dentro do segundo grupo, os reservatórios de Mogi-Guaçu e Euclides da Cunha foram muito próximos geneticamente, mesmo localizando-se em rios diferentes, porém fazem parte da mesma bacia hidrográfica. A similaridade entre Jurumirim e Salto Grande é justificada pela direção do fluxo de água. Em Jaguari, Paraibuna e Jurumirim, a proximidade genética dos materiais caracteriza reservatórios que sofreram ação antrópica, pelo fato de esses rios não pertencerem à mesma bacia hidrográfica. Materiais de pesca e a informação de que o aguapé é uma planta que "limpa" a água podem ter sido os motivos que incentivaram o homem a dispersá-la.

\section{LITERATURA CITADA}

LODHI, M. A. et al. A simple and efficient method for DNA extration from grapevine cultivars and Vitis sapequeis. Plant Molec. Biol. Reporter, v. 12, p. 6-13, 1994.
NEI, M. Genetic Distance beetween populations. Am. Natural., v. 106, p. 283-292, 1972.

NEWMAN, S.; HALLER, W. T. Mineral deficiency symptoms of. waterhyacinth. J. Aquatic. Plant Manag., v. 26, p. 55-8, 1988.

PEDRALLI, G. Aguapé: solução ou problema? Ci. Hoje, v. 9, n. 53, p. 76-77, 1989.

RYAN, F. J. Identification of monoecious and dioecious Hydrilla with the RAPD assay. In: AQUATIC weed control investigations. Rome: FAO, 1993a. p. 60. (Annual Report)

RYAN, F. J. Identification of the monoecious biotype of Hydrilla in Tulare County, CA. In: AQUATIC weed control investigations. Rome: FAO, 1993b. p. 62. (Annual Report)

SWARBRICK, J. T. Weeds of Australia, Salviniaceae, Primulaceae, Pontederiaceae. Aust. Weeds, v. 1, n. 10, p. 21-27, 1981.

WAIN, R. P.; HALLER, W. T.; MARTIN, D. F. Isoenzymes in studies of. aquatic plants. J. Aquatic Plant Manag., v. 23, p. 42-45, 1985.

WEISS, A. Survey of Egeria densa accessions for genetic similarity by Random Amplified Polymorphic DNA analysis (RAPDs). In: AQUATIC weed control Investigations. Rome: FAO, 1997. p. 69-73. (Annual Report)

WILLIAMS, J. G. K.; KUBELIK, A. R. K.; LIVAK, J. L. DNA polymorphisms amplified by arbitrary "primer"s are useful as genetic markers. Nucleic Acids Res., v. 18, p. 6531-6535, 1990. 